\title{
Morphometric variation in pink shrimp populations at Rio de Janeiro coast (SE Brazil): are they really similar in closer areas?
}

\author{
CÁSSIA DE CARVALHO ${ }^{1}$, KARINA A. KEUNECKE ${ }^{2}$ and HELENA P. LAVRADO ${ }^{1}$
}

\author{
${ }^{1}$ Programa de Pós-Graduação em Zoologia do Museu Nacional, Universidade Federal do Rio de \\ Janeiro (PPGZoo/MN-UFRJ), Departamento de Biologia Marinha, Instituto de Biologia, Av. Pau- \\ Brasil, 211, Prédio do CCS - Bloco A, Ilha do Fundão, 21949-900 Rio de Janeiro, RJ, Brazil \\ ${ }^{2}$ Departamento de Biologia Animal, Instituto de Ciências Biológicas e da Saúde, Universidade Federal \\ Rural do Rio de Janeiro, Rodovia BR 465, Km 7, 23897-000 Seropédica, RJ, Brazil
}

Manuscript received on March 9, 2018; accepted for publication on September 17, 2018

\begin{abstract}
How to cite: CARVALHO C, KEUNECKE KA AND LAVRADO HP. 2019. Morphometric variation in pink shrimp populations at Rio de Janeiro coast (SE Brazil): are they really similar in closer areas?. An Acad Bras Cienc 91:e20180252. DOI 10.1590/0001-3765201920180252.

Abstract: Farfantepenaeus brasiliensis and F. paulensis are the most exploited shrimps of SE-S Brazilian coast. Our aim was to verify if adjacent nursery areas with different environmental condition (Sepetiba and Guanabara bays, SE Brazil) influence on shrimp populations (eg, CPUE) and body shapes. Samplings were carried out during 12 months in those bays ca. $85 \mathrm{Km}$ far from each other. Carapace length (CL), total body length (TL), wet weight, abdomen size and TL/CL ratio were used to analyze variations in shape through regressions. In general, F. brasiliensis was 4 to 6 times more abundant than F. paulensis. The sex ratio differed from 1:1 in F. brasiliensis in both bays, with dominance of females, largest catches occur in autumn. However, differences in size and morphology were found between bays, mainly regarding the TL/CL ratio. Shrimps in Sepetiba Bay have higher TL/CL showing a more "elongated shape" (larger abdomen) when compared to those from Guanabara Bay. Results suggest the existence of an estuary vs shrimp morphology relationship which results in differences in body shape even in spatially close areas. TL/CL ratio has proven useful for assessing shrimp populations differences and might be tested for tracking the origin of adult shrimps stocks at the coast.
\end{abstract}

Key words: Farfantepenaeus brasiliensis, Farfantepenaeus paulensis, Guanabara Bay, morphometry, pink shrimps, Sepetiba Bay.

\section{INTRODUCTION}

Morphometric studies are considered one of the simplest, most commonly and cost-effective used tools to identify and characterize stocks or populations of fishes and crustaceans (Cadrin and Silva 2005, Bissaro et al. 2012). These studies can

Correspondence to: Cássia de Carvalho

E-mail: carvalho.c89@gmail.com

ORCid: https://orcid.org/0000-0003-4405-6789 potentially contribute to aquaculture purposes, management and conservation strategies for a population and lead to a better understanding of species ecology, behavioral traits and stock assessment (Chu et al. 1995, Cadrin and Silva 2005, Silva et al. 2009).

Morphological variability reflects both environmental and genetic influences. Some studies about populations of decapod crustaceans 
suggested these differences as possible adaptive responses to the environment (Chow and Sandifer 1991, Silva et al. 2009, Dumont and D'Incao 2010, Bissaro et al. 2012). This condition is common in species with wide geographical distribution, like some penaeids, and it is called phenotypic plasticity.

The penaeids shrimps Farfantepenaeus brasiliensis (Latreille 1817) and Farfantepenaeus paulensis (Pérez-Farfante 1967), commonly known as pink shrimps, are native to western Atlantic Ocean and are the most exploited shrimp species of Brazil (Valentini et al. 2012). Farfantepenaeus paulensis is found from $12^{\circ} \mathrm{S}$ (Bahia, Brazil) to $38^{\circ} \mathrm{S}$ (Mar del Plata, Argentina), while F. brasiliensis exhibits a wider geographical distribution from $35^{\circ} \mathrm{N}$ (North Carolina, USA) to $29^{\circ} \mathrm{S}$ (Rio Grande do Sul, Brazil). Their geographical distributions present an overlapping in the Southeast and South of Brazil, from $12^{\circ} \mathrm{S}$ to $29^{\circ} \mathrm{S}$ (Pérez-Farfante 1967, D'Incao 1991, Costa et al. 2003).

For these species, estuaries are essential to complete their life cycle (type II lifecycle, Dall et al. 1990). It includes an estuarine phase, when post-larvae enter the mouth of the estuaries, disperse into the inner reaches, settle and become juveniles, grow and subsequently migrate to the sea as sub-adults (Garcia and Le Reste 1981). The estuarine phase is characterized by rapid growth and continuous migration, thus generating a short residence time within estuaries (4 to 6 months, Garcia and Le Reste 1981, D'Incao 1991).

Guanabara and Sepetiba bays are important nursery grounds for pink shrimps at Rio de Janeiro State, SE Brazil (Dias Neto 2011). Those bays also support artisanal pink shrimp fisheries (Vianna 2009). They are close geographically (ca. $85 \mathrm{~km}$ ) but are different in terms of environmental conditions, including chlorophyll (higher at Guanabara Bay, Fiori et al. 2013) and water transparency (higher at Sepetiba Bay, Araújo et al. 2006). Both bays have suffered considerably from intense input of various sources of pollution and other human impacts as embankments and dredging. The main environmental issue in Guanabara Bay is the input of domestic sewage without treatment, while in Sepetiba Bay is the waste of heavy metals from industrial activities (Fiori et al. 2013). However, the bays still exhibit characteristics of typical tropical estuaries, such as high primary productivity and favourable conditions for growth and reproduction of many estuarine and marine species (Araújo et al. 2006, Gomes et al. 2013, Da Silva et al. 2016, Moraes and Lavrado 2017).

It has been reported that $F$. brasiliensis and $F$. paulensis shrimps present considerable intraspecific and interspecific variability (Teodoro et al. 2016). The morphometry of pink shrimps have already been investigated in continental shelf of the Southeast-South of Brazil (eg, Neto 1985, Leite Jr and Petrere Jr 2006) and in estuarine systems (eg, Branco and Verani 1998a, 1998b, Albertoni et al. 2003, Freitas Jr et al. 2011), but none of them with a comparative approach between geographically close areas. Most of the studies investigated differences in their spatial distribution and abundance without regarding morphological differences (eg, Costa et al. 2008, 2016, Lüchmann et al. 2008).

In this context, the aim of this work was to characterize and compare the population structure, size and morphological shape of $F$. brasiliensis and $F$. paulensis that coexist in two geographically close bays at SE Brazilian coast (Sepetiba Bay and Guanabara Bay). Although these bays are environmentally different, they do not seem to have any physical, geological and oceanographic barriers that may prevent dispersion. Our hypothesis is that adjacent nursery areas geographically close but environmentally different can influence on shrimp population structure and their body shapes. We also provide morphometric and population structure information which can be useful for shrimp stock identification purposes and for future shrimp management and monitoring programs in SE Brazilian coast. 


\section{MATERIALS AND METHODS}

\section{STUDY AREA}

The climate of the Rio de Janeiro State is classified as tropical wet with a relatively dry winter and intense rainfall in the summer (Kjerfve et al. 1997, SEMADS 2001). The dry period occurs from May to October while the rainy season occurs from November to April according to historical monthly rainfall data (Geo-Rio 2013). Some physical and hydrological characteristics of Guanabara Bay and Sepetiba Bay (Figure 1) are summarized in Table I.

Guanabara Bay is a highly eutrophic estuary located in the center of the metropolitan region of Rio de Janeiro city, southeastern Brazil (Figure 1) and is the second largest Brazilian bay in terms of area. Approximately 12 million inhabitants live within the Guanabara Bay drainage basin (SoaresGomes et al. 2016). This bay is strategically located adjacent to one of the most industrialized regions of the country and under the influence of numerous fishing and commercial port facilities, in addition to shipyards and oil refineries (Da Silva et al. 2016). Hydrological conditions are heterogeneous within the bay, depending on circulation patterns and pollution foci (Da Silva et al. 2016). During the summer, water column stratification is observed, forming a pycnocline. In winter, water conditions are more homogeneous (Ribeiro and Kjerfve 2002, Soares-Gomes et al. 2016).

Sepetiba Bay is a sedimentary embayment located ca. $85 \mathrm{~km}$ to the west of Guanabara Bay (Figure 1). Fifteen cities surround the bay ( $\sim 2$ million people). One of the largest port and industrial complexes of Brazil are located at its drainage area, and this complex continues arising at the present days (Fiori et al. 2013). It presents a circulation pattern resulting in great mixing in the water column and a low or nonexistent stratification (SEMADS 2001).

TABLE I

Main physical and hydrological characteristics of Guanabara Bay and Sepetiba Bay.

\begin{tabular}{|c|c|c|}
\hline & Guanabara Bay & Sepetiba Bay \\
\hline \multirow{2}{*}{ Coordinates } & $22^{\circ} 44^{\prime}-22^{\circ} 57^{\prime} \mathrm{S}$ & $22^{\circ} 53^{\prime}-23^{\circ} 04^{\prime} \mathrm{S}$ \\
\hline & $42^{\circ} 33^{\prime}-43^{\circ} 19^{\prime} \mathrm{W}$ & $43^{\circ} 34^{\prime}-44^{\circ} 10^{\prime} \mathrm{W}$ \\
\hline Area & $380 \mathrm{~km}^{2}$ (Soares-Gomes et al. 2016). & $305 \mathrm{~km}^{2}$ (SEMADS 2001). \\
\hline Salinity & $\begin{array}{l}13 \text { (inner areas) to } 34 \text { (central channel) (Soares- } \\
\text { Gomes et al. 2016). }\end{array}$ & $\begin{array}{l}20 \text { (inner areas) to } 34 \text { (near Restinga da Marambaia) } \\
\text { (SEMADS 2001). }\end{array}$ \\
\hline Depth & $\begin{array}{l}\text { The average depth is } 5.7 \mathrm{~m} \text { (maximum value } \\
-58 \mathrm{~m} \text { near the central channel) (Kjerve et al. } \\
\text { 1997, Costa 1998). }\end{array}$ & $\begin{array}{c}\text { From two to } 31 \mathrm{~m} \text { (near Itaguaí harbor), but } \sim 50 \% \text { of } \\
\text { its area is less than } 6 \mathrm{~m} \text { (SEMADS 2001). }\end{array}$ \\
\hline Tide mode & $\begin{array}{l}\text { Semi-diurnal tide }-0.7 \mathrm{~m} \text { tide range on average } \\
\text { (Da Silva et al. 2016). }\end{array}$ & $\begin{array}{l}\text { Semi-diurnal tide }-0.8 \mathrm{~m} \text { tide range on average } \\
\text { (SEMADS 2001). }\end{array}$ \\
\hline Sediments & $\begin{array}{l}\text { Bay mouth is mainly sandy; inner areas (south- } \\
\text { north) are mainly muddy (Soares-Gomes et al. } \\
\text { 1997). }\end{array}$ & $\begin{array}{l}\text { Outer areas are mainly sandy; inner areas (west-east) } \\
\text { are mainly muddy (SEMADS 2001). }\end{array}$ \\
\hline Water stratification & $\begin{array}{c}\text { Stratification mainly in summer period (Ribeiro } \\
\text { and Kjerfve 2002). }\end{array}$ & No evident stratification (SEMADS 2001). \\
\hline $\begin{array}{l}\text { Chlorophyll-a } \\
\quad(\mu \mathrm{g} / \mathrm{L})\end{array}$ & 20.00 (Fiori et al. 2013). & 4.22 (Fiori et al. 2013). \\
\hline \multirow{4}{*}{$\begin{array}{c}\text { Mean Water } \\
\text { transparency }(\mathrm{m})\end{array}$} & Inner area $-0.9(0.3)$ & Inner area $-1.7(0.1)$ \\
\hline & Middle area - $1.3(0.8)$ & Middle area - $2.9(0.1)$ \\
\hline & Outer area - $2.4(1.0)$ & Outer area - $3.6(0.2)$ \\
\hline & (Santi and Tavares 2009) & (Araújo et al. 2006) \\
\hline
\end{tabular}



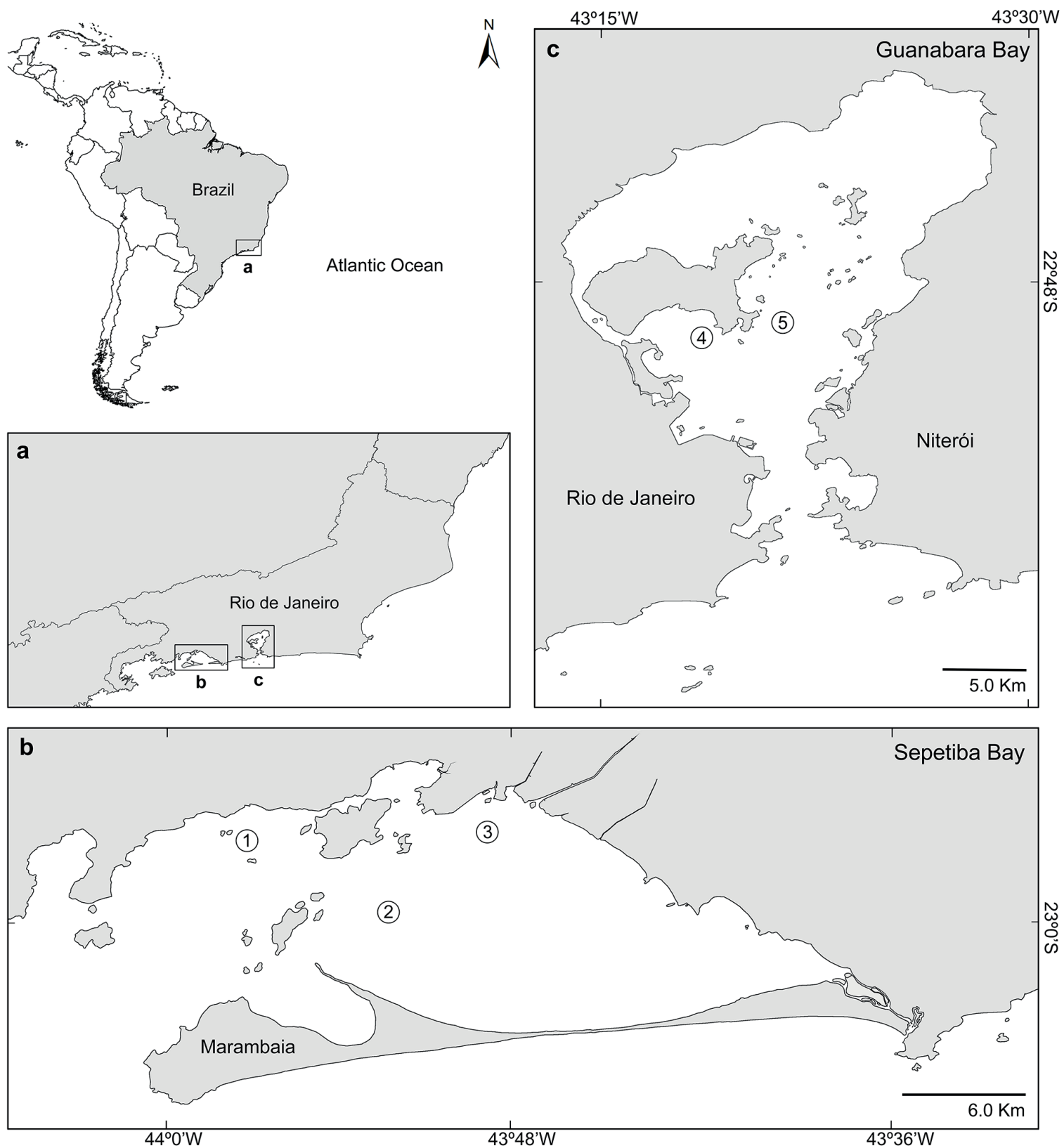

Figure 1 - (a) Rio de Janeiro State, Brazil. Sampling areas in (b) Sepetiba Bay: 1: outer; 2: central; 3: inner areas, and (c) Guanabara Bay: 4: Fundão; 5: central channel.

\section{SHRIMP SAMPLINGS AND LAB ANALYSIS}

Samplings were carried out during 12 consecutive months (August 2011 to July 2012). A typical 10-m long boat from the artisanal shrimp fleet was used, equipped with an 11-m long shrimp trawl net and a 20-mm mesh size at the cod end. Six experimental hauls (30 min per haul) were conducted per month in each bay, in zones with depths varying from 4 to $27 \mathrm{~m}$ in Guanabara Bay (near Fundão Island and central channel areas, Figure 1) and from 4 to $17 \mathrm{~m}$ in Sepetiba Bay (outer, central, inner areas, Figure 1). In laboratory, shrimps were kept frozen before analysis. The specimens were sexed and identified following Costa et al. (2003). The carapace length 
(distance from the postorbital margin to the middorsal posterior edge of the carapace, CL) and total body length (distance from the tip of the rostrum to the tip of the telson, TL) were taken using a digital caliper $( \pm 0.01 \mathrm{~mm})$. Analytical balance with accuracy of $0.01 \mathrm{~g}$ was used to record body wet weight $(\mathrm{W})$. The abdomen size $(\mathrm{ABD}, \mathrm{mm})$ was estimated by the difference between the total length and the carapace length including the rostrum.

Juvenile shrimps were those with $\leq 25 \mathrm{~mm}$ carapace length, while adult shrimps were those with $\geq 35 \mathrm{~mm}$ carapace length due to observation of developing gonads and Gomes et al. (2013).

\section{DATA ANALYSES}

The proportion of $F$. brasiliensis by $F$. paulensis was compared between bays using a Chi-square test $\left(\chi^{2}\right)$. The deviation from the theoretical sex ratio (1:1) for each species was also evaluated using $\chi^{2}$ (Zar 1999).

The CPUE average (individuals per haul) was calculated per season, bay, and species. A oneway Analysis of Variance (ANOVA) was used to compare CPUE by species between seasons in each bay. The CPUE data were $\log (\mathrm{x}+1)$ transformed when necessary in order to achieve the ANOVA assumptions of normality and homoscedasticity. $A$ posteriori Tukey's test was used to make pair wise comparisons (Zar 1999).

The means, standard deviations, maximumminimum values and coefficient of variation $(\mathrm{CV}$ $\%$ ) of all measurements (CL, TL, ABD, W) and TL/ $\mathrm{CL}$ ratio were recorded for each sex, species and bay. All variables were compared between bays, sexes or species using a Student t test (Zar 1999).

Linear $(\mathrm{TL}=\mathrm{a}+\mathrm{b} . \mathrm{CL})$ and nonlinear regressions $\left(\mathrm{W}=\mathrm{a} . \mathrm{TL}^{\mathrm{b}}\right)$ were used to evaluate the length-length and length-weight relationships. A Student t test was applied to evaluate the isometric nature of the length-weight relationships $(b=3)$. The same test was also applied to compare the slope (b) of the length-length regressions between sexes or bays. As very large samples may allow for an easier rejection of the null hypothesis even if there are small differences, the effect size of Cohen (Cohen 1988) was calculated a posteriori. Cohen's d values of less than 0.19 indicate a very small effect size which means that the magnitude of the differences between groups are biologically irrelevant even it is statistically significant. Cohen's $U_{3}$ was also calculated as a measure of non-overlap, i.e., the percentage of population A that will be above the mean of the population B.

All statistical analyses were performed using Statistica 7 for Windows and R software with a 5\% significance level.

\section{RESULTS}

A total of 7,243 F. brasiliensis and 1,518 F. paulensis specimens were examined. From those, 4,267 shrimps were sampled in Guanabara Bay (GB) and 4,494 in Sepetiba Bay (SB) during the study period. The total abundances of each species was similar in both bays (Table II), but the ratio of $F$. brasiliensis/F. paulensis was significantly different between bays $\left(\mathrm{GB}=3.91: 1, \mathrm{SB}=5.91: 1, \chi^{2}=48.17\right.$, $\mathrm{p}<0.05)$. The ratio in $\mathrm{SB}$ is ca.1.5 times higher than that found in GB. In general, females are more abundant than males for both species in both bays, but the sex ratio was significantly different from 1:1 only for F. brasiliensis in both bays (Table II).

The species CPUE values were statistically different among seasons only in SB (Table III) with larger catches recorded in autumn: AprilJune $(\mathrm{F}=4.71, \mathrm{p}=0.005$ and $\mathrm{F}=8.10, \mathrm{p}=0.0001$ for $F$. paulensis and $F$. brasiliensis, respectively). A similar trend was found for $F$. paulensis in GB ( $\mathrm{F}=2.66, \mathrm{p}=0.06$, Table III), but the same did not occur with $F$. brasiliensis $(\mathrm{F}=0.48, \mathrm{p}=0.70)$ probably due to CPUE variation between seasons (standard deviation values, Table III). 
TABLE II

Total abundance and sex ratio for each species (F. brasiliensis and $F$. paulensis) and bay. P-values in bold indicate significant departure from the 1:1 sex ratio (Chi-square test, $p<0.05$ ).

\begin{tabular}{ccccccc}
\hline Species & Bay & Females (n) & Males (n) & $\begin{array}{c}\text { Sex ratio } \\
\text { F:M }\end{array}$ & $\chi^{2}$ & p-value \\
\hline \multirow{2}{*}{ F. brasiliensis } & Sepetiba & 1,998 & 1,846 & 1.08 & $\mathbf{6 . 0 1}$ & $\mathbf{0 . 0 1 3}$ \\
& Guanabara & 1,802 & 1,597 & 1.13 & $\mathbf{1 2 . 3 6}$ & $\mathbf{0 . 0 0 1}$ \\
\multirow{2}{*}{ F. paulensis } & Sepetiba & 332 & 318 & 1.04 & 0.006 & 0.610 \\
& Guanabara & 437 & 431 & 1.01 & 0.041 & 0.860 \\
\hline
\end{tabular}

TABLE III

Comparison of CPUE average ( $\mathrm{n}^{0}$ ind/30-min haul) of pink shrimp species (F. brasiliensis and F. paulensis) per season.

\begin{tabular}{cccccc}
\hline \multirow{2}{*}{ Bay } & \multirow{2}{*}{ Species } & \multicolumn{4}{c}{ Season } \\
\cline { 2 - 5 } & F. brasiliensis & $9.7 \pm 8.4^{\mathrm{a}}$ & $34.3 \pm 40.1^{\mathrm{a}}$ & $105.9 \pm 184.8^{\mathrm{a}}$ & $36.5 \pm 40.3^{\mathrm{a}}$ \\
\hline \multirow{2}{*}{ GB } & F. paulensis & $0.6 \pm 0.9^{\mathrm{a}}$ & $3.6 \pm 7.7^{\mathrm{a}}$ & $35.1 \pm 81.6^{\mathrm{a}}$ & $8.3 \pm 14.3^{\mathrm{a}}$ \\
\hline \multirow{2}{*}{ SB } & F. brasiliensis & $12.8 \pm 9.2^{\mathrm{ab}}$ & $61.3 \pm 56.7^{\mathrm{bc}}$ & $88.8 \pm 58.0^{\mathrm{c}}$ & $50.3 \pm 89.1^{\mathrm{a}}$ \\
& F. paulensis & $2.1 \pm 3.1^{\mathrm{a}}$ & $7.4 \pm 11.0^{\mathrm{ab}}$ & $18.3 \pm 17.6^{\mathrm{b}}$ & $8.4 \pm 18.3^{\mathrm{a}}$ \\
\hline
\end{tabular}

$\mathrm{GB}=$ Guanabara Bay; SB = Sepetiba Bay; spring = Sep-Nov/2011; summer = Dec/11-Feb/12; autumn = Mar-May/12; winter = Aug/11 and Jun-Jul/12. Different letters indicate significant differences (one-way ANOVA, $p<0.05$ ), considering by species and bay, $\mathrm{n}=18$ (hauls per season).

More than $97 \%$ of the shrimp sampled in the bays were juveniles or subadults (carapace length $>25 \mathrm{~mm}$ and $<35 \mathrm{~mm}$ ). Considering the biometric variables, the abdomen (ABD) and total length (TL) was significantly greater for Sepetiba Bay individuals (exception for TL in males of F. paulensis, Table IV). For both species, the individuals from $\mathrm{SB}$ also showed greater TL/CL ratios. The mean value of TL/CL ratio was 4.6 in $\mathrm{SB}$, being higher than GB (4.1 to 4.3 , Table IV). That ratio showed to be very stable within each population (CV less than 10\%) considering the CLsize range of the collected shrimps (10-45 $\mathrm{mm}$ for F. brasiliensis and $8-50 \mathrm{~mm}$ for $F$. paulensis) and it distinguishes individuals between bays. The high values of Cohen's $d$ and Cohen's $U_{3}$ indicate that the statistical differences are biologically relevant (Table III). For example, a Cohen's d of 1.99 (for differences of $F$. brasiliensis males TL/CL averages between bays) means that $97.7 \%$ of individuals from Sepetiba have TL/CL ratio above the average ratio value of males from Guanabara Bay (Table IV). The differences in TL/CL ratios were larger for $F$. brasiliensis than those for $F$. paulensis (t-values and Cohen's d).

The TL-CLrelationships were also significantly different between bays for both species and different between sexes (exception for F. brasiliensis in GB, Tables V and VI, Figure 2). But Cohen's d values $>$ 1.15 were detected only when comparing the bays, which means that the TL growth variation was more related to areas rather than to sex (Table VII). The abdomen size increases faster than the carapace for Sepetiba individuals as the shrimp grows in length. The differences in TL-CL relationships were larger also for $F$. brasiliensis than $F$. paulensis.

The pink shrimps from Sepetiba Bay presented a negative allometry ( $b<3, \mathrm{~W}$-TL relationship) while those from Guanabara Bay presented a positive allometry, $\mathrm{b}>3$, with the exception of $F$. brasiliensis males (Table VII), indicating the increase in length was greater than weight in individuals of $\mathrm{SB}$, the 

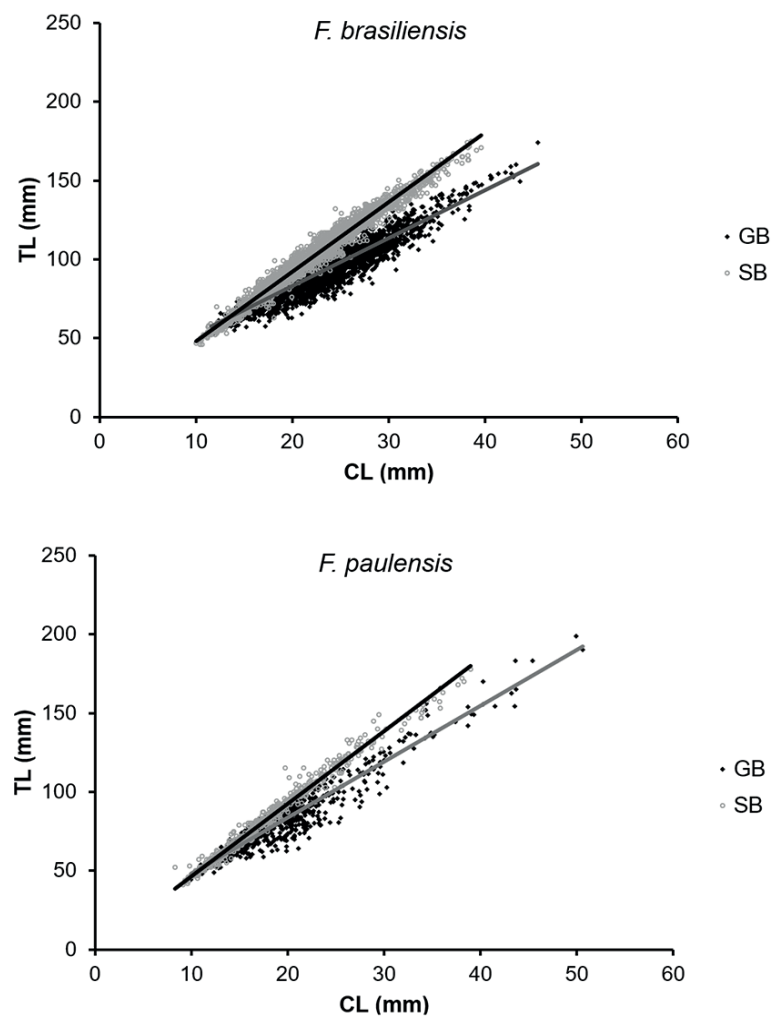

Figure 2 - Linear regressions (total length-carapace length relationship) for F. brasiliensis and F. paulensis. Black crosses = Guanabara Bay shrimps; Grey circles = Sepetiba Bay shrimps. TL = total length $(\mathrm{mm}) ; \mathrm{CL}=$ carapace length $(\mathrm{mm})$; $\mathrm{GB}=$ Guanabara Bay; SB = Sepetiba Bay.

opposite occurring in GB. The $b$ coefficient was also different between bays with very large or large size effect for F. paulensis (Table VIII). However, when comparing females and males in each bay, the $b$ value was significantly different for the two species only in Sepetiba Bay (Table VIII).

\section{DISCUSSION}

The dominance of $F$. brasiliensis over F. paulensis, observed in this study, is common in lower latitudes in the Southern hemisphere $\left(12^{\circ} \mathrm{S}\right)$, while the presence of $F$. brasiliensis in latitudes further south (close to its southern limit of distribution) is occasional according D'Incao et al. (2002). However, this tendency is not an ecological pattern (Table IX) because no evident latitudinal variation of the $F$. brasiliensis / F. paulensis ratio $(\mathrm{Fb} / \mathrm{Fp})$ was observed. The dominance of $F$. brasiliensis occurred in shallow coastal areas (bays, lagoons) and continental shelf in Brazilian tropical and subtropical areas (Table IX). On the other hand, the dominance of $F$. paulensis can be observed only in very shallow estuarine areas from $27^{\circ} 30^{\prime} \mathrm{S}$ (Table IX). Freitas et al. (2011) also found a large variation of the $\mathrm{Fb} / \mathrm{Fp}$ ratio (1.39-7.70) during the study period (1997-2006) in Saco dos Limões, Southern Bay, Santa Catarina, Brazil (Table IX). The authors suggested that this variation was associated with interannual mortality and recruitment variability of $F$. brasiliensis, since F. paulensis populations remained stable over time. But the increase of anthropogenic influence (effluent discharge and dredging activities have been increasing since 1995 in the region) may represent an important driving factor for the observed changes in the ratio of these species. In Imboassica lagoon, on the northeast coast of the Rio de Janeiro state, the variation of $\mathrm{Fb} / \mathrm{Fp}$ ratio was 0.50-6.10 (Albertoni et al. 2003, average value in Table IX). This lagoon is characterized by presenting events of "man-made openings" throughout the year. Albertoni et al. (2003) reported that the changes in environmental conditions of Imboassica lagoon reflected negatively on the relative condition factor and growth rates of $F$. brasiliensis and $F$. paulensis species. The observed variation of $\mathrm{Fb} / \mathrm{Fp}$ ratio along their distribution range suggests the existence of a habitat partition between the species caused by recruitment and mortality events as well as anthropogenic action rather than by latitudinal gradients.

We found a clear change in the $\mathrm{Fb} / \mathrm{Fp}$ ratio in Sepetiba Bay after almost 30 years (Table IX). The species F. brasiliensis and F. paulensis occurred at approximately $0.51-1.37 \mathrm{Fb} / \mathrm{Fp}$ ratio of shrimp catches in Sepetiba Bay almost three decades ago (Oshiro and Araújo 1987). On the other hand, after a 10 -year period, little variation in this ratio was found in Guanabara Bay compared to that found 


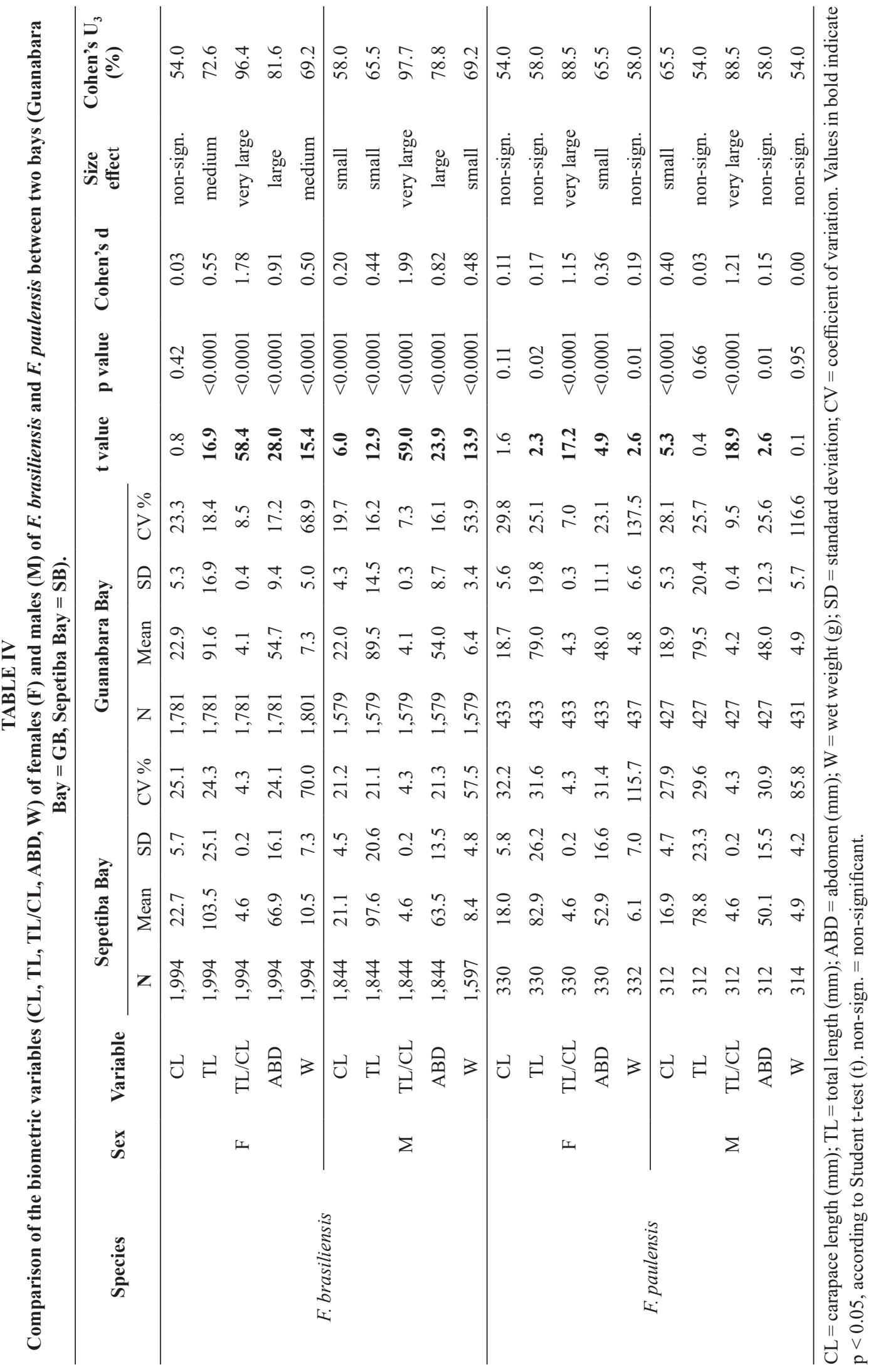


TABLE V

Parameter values of the equation $\mathrm{TL}=\mathrm{a}+\mathrm{b}$.CL for each sex, species (F. brasiliensis and $F$. paulensis) and bay.

\begin{tabular}{|c|c|c|c|c|c|c|}
\hline Species & Bay & Sex & $\mathbf{N}$ & $\mathbf{a} \pm \mathbf{S E}$ & $\mathbf{b} \pm \mathbf{S E}$ & $\mathbf{r}^{2}$ \\
\hline \multirow{6}{*}{ F. brasiliensis } & \multirow{3}{*}{ Sepetiba } & $\mathrm{F}$ & 1,994 & $4.57 \pm 0.33$ & $4.36 \pm 0.01$ & 0.98 \\
\hline & & M & 1,844 & $1.82 \pm 0.38$ & $4.53 \pm 0.02$ & 0.97 \\
\hline & & Grouped sexes & 3,838 & $3.90 \pm 0.25$ & $4.41 \pm 0.01$ & 0.98 \\
\hline & \multirow{3}{*}{ Guanabara } & $\mathrm{F}$ & 1,781 & $22.63 \pm 0.62$ & $3.02 \pm 0.03$ & 0.94 \\
\hline & & M & 1,579 & $22.07 \pm 0.78$ & $3.06 \pm 0.03$ & 0.83 \\
\hline & & Grouped sexes & 3,360 & $22.52 \pm 0.48$ & $3.03 \pm 0.02$ & 0.93 \\
\hline \multirow{6}{*}{ F. paulensis } & \multirow{3}{*}{ Sepetiba } & $\mathrm{F}$ & 330 & $3.04 \pm 0.66$ & $4.44 \pm 0.03$ & 0.98 \\
\hline & & M & 312 & $-4.05 \pm 0.54$ & $4.90 \pm 0.03$ & 0.99 \\
\hline & & Grouped sexes & 642 & $0.45 \pm 0.46$ & $4.61 \pm 0.03$ & 0.98 \\
\hline & \multirow{3}{*}{ Guanabara } & F & 433 & $14.50 \pm 0.80$ & $3.46 \pm 0.04$ & 0.94 \\
\hline & & M & 427 & $10.54 \pm 1.16$ & $3.64 \pm 0.06$ & 0.90 \\
\hline & & Grouped sexes & 860 & $12.65 \pm 0.70$ & $3.55 \pm 0.04$ & 0.96 \\
\hline
\end{tabular}

$\mathrm{TL}=$ total length $(\mathrm{mm}) ; \mathrm{CL}=$ carapace length $(\mathrm{mm}) ; \mathrm{F}=$ females; $\mathrm{M}=$ males; $\mathrm{SE}=$ standard error.

TABLE VI

Comparisons of $b$ values (TL=a+b.CL) for each sex, species (F. brasiliensis and $F$. paulensis) and bay.

\begin{tabular}{|c|c|c|c|c|c|c|}
\hline Species & Sex & Bays & t-value & Cohen's d & Size effect & $\begin{array}{c}\text { Cohen's } U_{3} \\
(\%)\end{array}$ \\
\hline \multirow{5}{*}{ F. brasiliensis } & $\mathrm{F}$ & $\mathrm{SB} \times \mathrm{GB}$ & 33.04 & 1.50 & very large & 93.3 \\
\hline & M & SB x GB & 28.22 & 1.35 & very large & 91.9 \\
\hline & Grouped sexes & $\mathrm{SB} \times \mathrm{GB}$ & 42.99 & 1.42 & very large & 91.9 \\
\hline & $\mathrm{F} \times \mathrm{M}$ & SB & 5.40 & 0.25 & small & 61.8 \\
\hline & $\mathrm{F} \times \mathrm{M}$ & GB & 0.66 & 0.03 & non-sig. & $<54.0$ \\
\hline \multirow{5}{*}{ F. paulensis } & $\mathrm{F}$ & $\mathrm{SB} \times \mathrm{GB}$ & 12.77 & 1.27 & large & 90.3 \\
\hline & M & $\mathrm{SB} \times \mathrm{GB}$ & 13.99 & 1.27 & large & 90.3 \\
\hline & Grouped sexes & $\mathrm{SB} \times \mathrm{GB}$ & 17.38 & 1.18 & large & 88.5 \\
\hline & $\mathrm{F} \times \mathrm{M}$ & SB & 7.00 & 0.78 & medium & 78.8 \\
\hline & $\mathrm{F} \times \mathrm{M}$ & GB & 1.83 & 0.17 & non-sig. & 57.9 \\
\hline
\end{tabular}

$\mathrm{TL}=$ total length $(\mathrm{mm}) ; \mathrm{CL}=$ carapace length $(\mathrm{mm})$ between sexes or bays. Values in bold indicate $\mathrm{p}<0.05$ according to Student t-test (t). $\mathrm{F}=$ females; $\mathrm{M}=$ males; $\mathrm{SB}=$ Sepetiba Bay; $\mathrm{GB}=$ Guanabara Bay; non-sig. = non-significant.

by P.M. Golodne (unpublished data, Table IX). Our results suggest a demographic change of pink shrimp populations in Sepetiba Bay not related to large-scale environmental changes (hundreds of $\mathrm{km})$. In both bays, pink shrimps are the most abundant shrimp species (Oshiro and Araujo, 1987, Lavrado et al. 2000), but there are no studies about long-term temporal changes regarding other shrimp species that could be used for comparisons. Future studies are needed to follow up these populations in these bays to clarify which are the local environmental drivers of those temporal changes.

Sexual ratio is a feature that reflects population balance (Fisher 1930) and the ratio of $1: 1$ in penaeids shrimps is very common (Dall et al. 1990). However, the sex ratio differs from the 
TABLE VII

Parameter values of the equation $\mathrm{W}=\mathrm{a} . \mathrm{TL}^{\mathrm{b}}$ for each sex, species (F. brasiliensis and $F$. paulensis) and bay.

\begin{tabular}{|c|c|c|c|c|c|c|c|}
\hline Species & Bay & Sex & $\mathbf{N}$ & $a\left(x 10^{-5}\right)$ & $\mathbf{b} \pm \mathbf{S E}$ & t-value & $\mathbf{r}^{2}$ \\
\hline \multirow{6}{*}{ F. brasiliensis } & \multirow{3}{*}{ Sepetiba } & Females & 1,681 & 1.00 & $2.96 \pm 0.01$ & 2.87 & 0.97 \\
\hline & & Males & 1,541 & 1.50 & $2.86 \pm 0.02$ & 7.89 & 0.96 \\
\hline & & Grouped sexes & 3,222 & 1.00 & $2.96 \pm 0.01$ & 3.75 & 0.97 \\
\hline & \multirow{3}{*}{ Guanabara } & Females & 1,696 & 0.70 & $3.05 \pm 0.01$ & 3.98 & 0.96 \\
\hline & & Males & 1,517 & 0.70 & $3.02 \pm 0.02$ & 1.26 & 0.94 \\
\hline & & Grouped sexes & 3,213 & 0.60 & $3.06 \pm 0.01$ & 5.78 & 0.91 \\
\hline \multirow{6}{*}{ F. paulensis } & \multirow{3}{*}{ Sepetiba } & Females & 267 & 1.20 & $2.91 \pm 0.02$ & 4.33 & 0.99 \\
\hline & & Males & 252 & 2.90 & $2.71 \pm 0.03$ & 10.00 & 0.98 \\
\hline & & Grouped sexes & 519 & 1.20 & $2.92 \pm 0.02$ & 4.94 & 0.98 \\
\hline & \multirow{3}{*}{ Guanabara } & Females & 399 & 0.50 & $3.10 \pm 0.01$ & 7.02 & 0.99 \\
\hline & & Males & 403 & 0.40 & $3.13 \pm 0.02$ & 7.41 & 0.99 \\
\hline & & Grouped sexes & 802 & 0.50 & $3.11 \pm 0.01$ & 10.11 & 0.99 \\
\hline
\end{tabular}

$\mathrm{W}=$ wet weight $(\mathrm{g}) ; \mathrm{TL}=$ total length $(\mathrm{mm}) ; \mathrm{SE}=$ standard error. Values in bold indicate $\mathrm{p}<0.05,(\mathrm{~b} \neq 3)$, according to Student $\mathrm{t}$-test (t).

TABLE VIII

Comparisons of $b$ values $\left(\mathrm{W}=\mathbf{a} . T_{L}\right)$ for each sex, species $(F$. brasiliensis and $F$. paulensis) and bay.

\begin{tabular}{lcccccc}
\hline Species & Sex & Bays & t & Cohen's d & Size effect & $\begin{array}{c}\text { Cohen's U } \\
(\mathbf{\%})\end{array}$ \\
\hline F. brasiliensis & Females & SB x GB & $\mathbf{3 . 4 0}$ & 0.32 & small & 61.8 \\
F. brasiliensis & Males & SB x GB & $\mathbf{4 . 5 1}$ & 0.33 & small & 61.8 \\
F. brasiliensis & Grouped sexes & SB x GB & $\mathbf{4 . 6 9}$ & 0.26 & small & 61.8 \\
F. brasiliensis & Females x Males & SB & $\mathbf{3 . 2 1}$ & 0.27 & small & 61.8 \\
F. brasiliensis & Females x Males & GB & 0.88 & 0.05 & non-sig. & 54.0 \\
\hline F. paulensis & Females & SB x GB & $\mathbf{5 . 4 5}$ & 2.02 & very large & 97.7 \\
F. paulensis & Males & SB x GB & $\mathbf{9 . 0 4}$ & 2.73 & very large & 99.7 \\
F. paulensis & Grouped sexes & SB x GB & $\mathbf{6 . 9 5}$ & 1.64 & very large & 94.5 \\
F. paulensis & Females x Males & SB & $\mathbf{4 . 1 1}$ & 1.26 & large & 90.3 \\
F. paulensis & Females x Males & GB & 0.79 & 0.72 & medium & 75.8 \\
\hline
\end{tabular}

$\mathrm{W}=$ wet weight $(\mathrm{g}) ; \mathrm{TL}=$ total length $(\mathrm{mm})$ between sexes and/or between bays. Values in bold indicate $\mathrm{p}<0.05$, ( $\mathrm{b} \neq 3$ ), according to Student t-test (t). SB = Sepetiba Bay; GB = Guanabara Bay; non-sig. = non-significant.

expected ratio of 1:1 for $F$. brasiliensis in both bays in the present study. Possible causes for that difference are the existence of a segregated distribution (spatial partition between males and females) and/or differential mortality associated to dimorphism in growth between sexes, where males usually have larger constant k, and consequently, higher mortality rates (Garcia and Le Reste 1986,
Dall et al. 1990). Besides, the sexual dimorphism in size (females being bigger than males) might result in higher mesh size selection during trawling, leading to the biased proportion toward females (Kevrekidis and Thessalou-Legaki 2006).

According to Geisel (1972), populations that are physiologically and behaviorally homeostatic and occupy relatively constant environments tend 
to show the sexual ratio of 1:1 or a slightly increased ratio in the number of males. On the other hand, populations inhabiting variable environments will show an increase in the number of females in order to maximize the evolutionary potential due to unequal selection between the sexes. Guanabara Bay (GB) and Sepetiba Bay (SB) have been both suffering from anthropic impacts for decades, mainly as a result of urbanization and disordered industrial development causing significant changes in these ecosystems and making them more variable. In turn, this may be reflecting on the balance of these populations, especially $F$. brasiliensis, increasing the number of females over time. Previous studies at Guanabara Bay (P.M. Golodne, unpublished data, Table IX) and Sepetiba Bay (L.M.Y. Oshiro et al., unpublished data, Table IX) did not reveal a significant difference in $F$. brasiliensis sex ratio a decade ago (2005-2007 in GB and 2004-2005 in SB) which suggests an increase in male mortality due to environmental changes on a regional scale (tens to hundreds of $\mathrm{km}$ ) such as coastal circulation or rainfall variation.

These large-scale factors could also explain the annual variation of CPUE of the species in the two bays (Table III). Although the seasonal variation was significantly different only in SB, it followed the same trend in GB with a peak in autumn followed by a decrease in winter. The main cues for the migration of juveniles to offshore areas involve intrinsic factors (eg, shrimp size) but also extrinsic factors (eg, rainfall and temperature, Dall et al. 1990, Costa et al. 2008). Rainfall and temperature presented similar oscillations in the study region. Thus, the migration of pink shrimps from nursery areas to offshore areas appeared to follow the same environmental cues.

In general, differences in size and morphology between bays were observed in all analyses in the present study. Even using few morphometric variables, our results point out relevant morphological differences of both species in two geographically close bays, which may indicate different subpopulations or phenotypic variability. Some attempts have already been made to identify differences in morphometric traits and correlate such traits with geographic location for some penaeids shrimp species for fishing management or genetic resources (Barcia et al. 2005, Paramo and Saint-Paul 2010, Carvalho-Batista et al. 2014). However, other authors showed that natural populations of penaeids shrimps do not appear to be finely subdivided (Chow and Sandifer 1991, Gusmão et al. 2005, Teodoro et al. 2015). A genetic homogeneity among shrimps on the Brazilian coast have been reported for Artemesia longinaris Bate 1888 (Carvalho-Batista et al. 2014), F. brasiliensis (Gusmão et al. 2005), L. schmitti (Burkenroad 1936) (Gusmão et al. 2005) and F. paulensis (Teodoro et al. 2015). The populations homogeneity was justified by the larval dispersal period (around 12 to 21 days) characterized by larval development up to the first post-larval stage (settlement) (Dall et al. 1990). Swimming capacity and migratory movements of sub-adult and adult individuals may also contribute to mixing the gene pool of populations. The fisheries effort in shrimp populations were also indicated as a factor of population homogenization (Barcia et al. 2005, Gusmão et al. 2005, Teodoro et al. 2015). Considering the fishing pressure on the penaeids shrimps stocks for several decades, a reduction in the genetic diversity of these organisms is to be expected. In Brazil, pink shrimp industrial fisheries has been taking place for more than five decades and by the end of 1970's a reduction in stocks has already been detected (D'Incao et al. 2002, Valentini et al. 2012).

Considering that most individuals are juveniles or sub adults of both bays and genetically similar, this leads us to infer that differences in environmental conditions influence on the shrimp metabolism and growth (k parameter, for example) causing the observed differences in their body shapes. Similar results were found for $F$. brasiliensis 


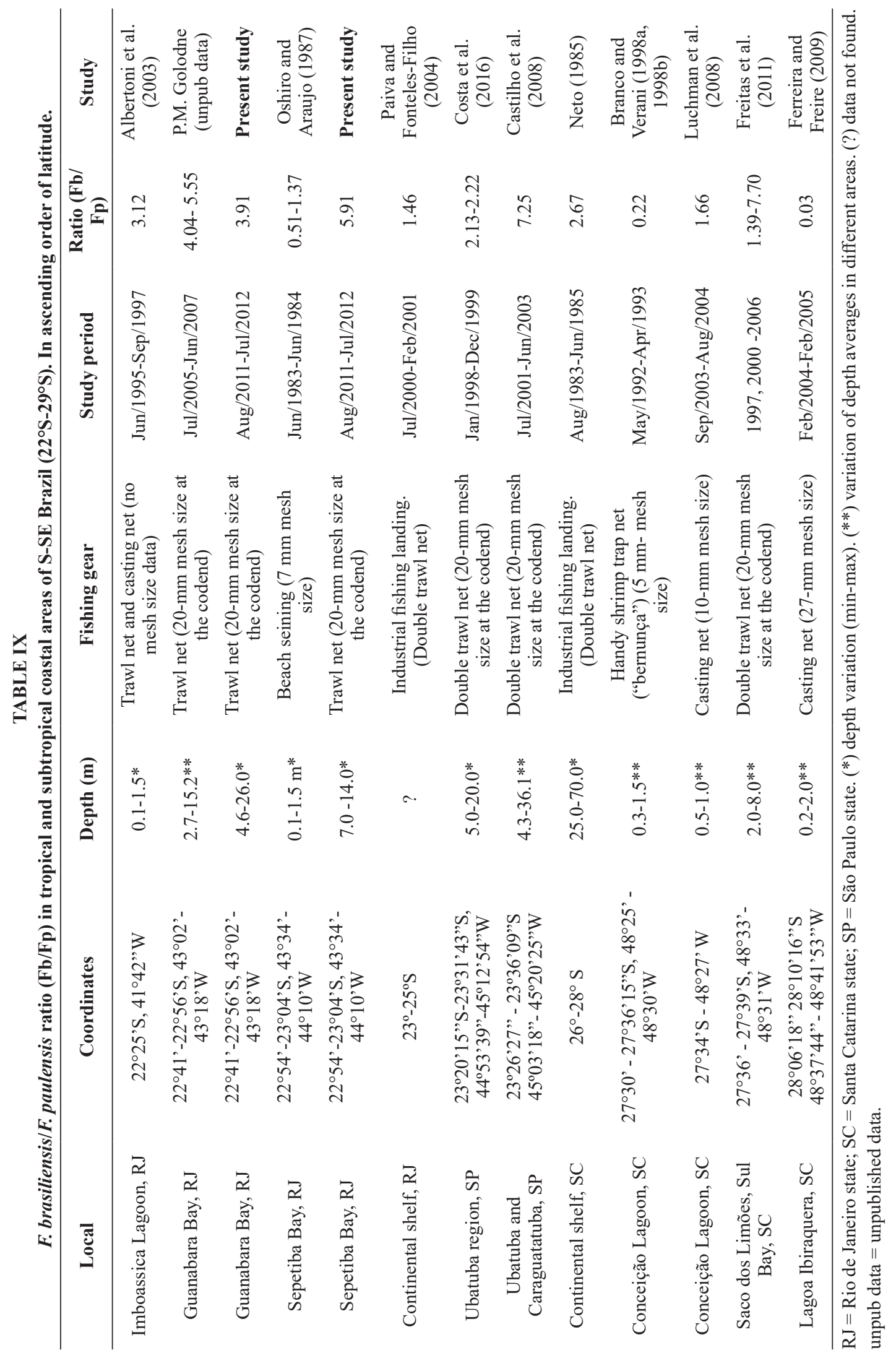


on the northeast coast of Brazil ( $5^{\circ} 11^{\prime \prime} 56^{\prime}$ $6^{\circ} 22^{\prime} 10^{\prime \prime} \mathrm{S}$ and $35^{\circ} 00^{\prime \prime}-35^{\circ} 25^{\prime} \mathrm{W}-$ A.P. Pinheiro, unpublished data). That author found significant morphometric differences (CL, TL, ABD and W) for $F$. brasiliensis between sites, mainly when the sexes were grouped. Females of F. brasiliensis were more different between sites than males but $\mathrm{F}_{\text {st }}$ values did not show genetic structuring.

There is a consensus on the influence of environmental conditions on morphological variability of certain body structures such as size and shape of carapace, rostrum and abdomen. For Penaeus monodon Fabricius 1798 populations in Indian Ocean, the extensive morphometric variability found was mainly due to variation in carapace length and width, with males presenting more evident phenotypic differences among areas (Sun et al. 2014). The phenotypic plasticity of size and shape of the chelae also occur in some brachyurans, being related to responses to environmental cues such as food availability (diet) and temperature (Smith 2004, Baldridge and Smith 2008, Silva et al. 2009). In addition, variation of one structure may be more evident than another, as reported by Brian et al. (2006) for Carcinus maenas (Linnaeus 1758), where the variation in chelae shape was more conspicuous than the variation in carapace shape.

In the present study, the TL/CL ratio variation between bays was more evident than carapace length (CL) and total length (TL). Sepetiba Bay shrimps had a more "elongated shape" (greater TL/CL ratios) while shrimps from the Guanabara Bay had a "shorter shape". The differences mainly lie in the size of abdomen, which is larger in SB individuals. Those differences in shape may also be related to differences in shrimp diets between bays. The isotopic composition of shrimps (C. Carvalho, unpublished data) showed that SB individuals have higher nitrogen isotope levels $\left(\delta^{15} \mathrm{~N}\right.$, mean value $=12.3 \%$ ) than those from Guanabara Bay (mean value $=7.5 \%$ ). This suggests that SB shrimps may occupy a higher trophic position, ingesting different preys which in turn can influence on the weight and abdomen size during growth. It has been already known that $F$. paulensis and $F$. brasiliensis increase in weight when they are submitted to a protein-rich diet (Ballester et al. 2010). On the other hand, the stress due to organic pollution may also interfere on shrimp growth. Guanabara Bay is more eutrophic than Sepetiba Bay and has a lower water quality level and a higher ecological risk for the marine biota (Fiori et al. 2013). In that case, the high energy costs associated to a poor quality food could reduce the abdomen growth in length even if total weight remains higher for GB individuals as a function of higher food availability.

Differences in ratio (TL/CL) were observed in both sexes. Larger abdomen in female prawns of the infraorder Caridea is common because they carry their eggs in the pleopod until hatching, but this reproductive behavior does not occur with penaeids. The ontogenetic variation in the abdomen size exists in some Decapoda (eg, Astacidea, Caridea) (Arnott et al. 1998). Astacidea juveniles present a larger abdomen compared to adults in response to predators by tail-flipping, while adults use their claws against predators (Arnott et al. 1998). So, a larger abdomen in juveniles may favor the escape from visual predators, such as fishes, squids and cetaceans. That feature can represent an advantage for the pink shrimps on Sepetiba Bay, where waters are less turbid than those from Guanabara Bay (Araújo et al. 2006, Table I).

It is known that interactive effects of environment, natural selection, and genotype variation on individual ontogeny produce morphometric differences within a species and between different geographic areas (Cadrin 2000). Thus, the existence of estuary $v s$ shrimp life cycle (types I, II or III, Dall et al. 1990) relationship can result in differences of population structure in spatially close areas even when those areas are not separated by evident physical, geological and 
oceanographic barriers. This variation usually is a result of differences in development rates of each species where morphometric discrimination is probably the result of different feeding strategies, reproductive rates and growth, for example (Cadrin 2000). Variations in parameters such as body size, sexual maturity and longevity are influenced by habitat conditions correlated with latitude (eg, water temperature and food/nutrient supply) (Castilho et al. 2007). Considering that a 30-mm CL pink shrimps are at least 9-11 months old in both bays (using growth equations found in D'Incao 1991) and that post-larvae usually penetrate an estuary by the age of one month, pink shrimps remain inside the bays time enough to have their morphology and growth be affected by habitat conditions.

Although morphometric differences are found in F. brasiliensis and F. paulensis in the present study, this cannot be generalized for the whole genus Farfantepenaeus Burukovsky, 1997. The morphometrics of F. notialis Pérez-Farfante, 1967 in four different geographical regions along the Colombian Caribbean Sea, for instance, showed great homogeneity indicating the existence of a single population (Paramo and Saint-Paul 2010). In that case, authors suggested that the environmental conditions could not induce different morphologies in individuals of those four localities.

The TL/CL ratio proved to be a good indicator of phenotypic plasticity among subpopulations of pink shrimp in those two geographically close bays. The measurements of total length and carapace length are commonly and easily measured which makes the use of TL/CL ratio easy and suitable for other penaeids species. Considering the commercial importance of pink shrimps, further studies are needed in order to detect other morphometric differences (eg, rostrum length, width and height of abdomen, width and height of carapace) that could be used for tracking the presence of subpopulations or even the estuarine origin of the coastal shrimp stocks especially in geographically close areas. Stocks are often defined using body morphometrics or life history traits from juveniles or adults captured at different areas. The phenotypic variability has been used in fish stocks identification (Burke et al. 2000, O'Neill et al. 2012). Differences in fish size, development, growth or even fin ray counts of juveniles between different nursery grounds were proposed as a useful tool for fish stock identification. Recently, morphological differences were successfully used for deep-sea shrimp populations identification (Purushothaman et al. 2017) reinforcing the use of morphometrics also for shrimp stock identification.

Our results indicate a clear phenotypic variability of the pink shrimp populations in SE Brazilian coast despite the absence of a significant genetic variability (reported to date). Thus, the same genotype may be associated with different phenotypes under different environmental conditions even at geographically closer areas (tens to hundreds of kilometers). This phenotypic plasticity contributes for the species acclimation in dynamic and stressful habitats, such as estuaries, and it could be also used as a clue for tracking the estuarine origin of pink shrimp stocks during fishing resources management actions along the coast.

\section{ACKNOWLEDGMENTS}

This research was supported by grant from Fundação Carlos Chagas Filho de Amparo à Pesquisa no Estado do Rio de Janeiro (FAPERJ -\#E26/111584/2014) and by Conselho Nacional de Desenvolvimento Científico e Tecnológico (CNPq - \#403809/2012-6) to Programa Ecológico de Longa Duração da Baía de Guanabara (PELD - Guanabara). It is also supported by a grant from FAPERJ to the project "Bioecological bases on two species of native penaeids shrimps in the Rio de Janeiro State: subsidies for fishery management, cultivation and maintenance of biodiversity" 
(\#E26/111.571/2010)". Authors are grateful to Professor Jean L. Valentin, coordinator of PELD - Guanabara and Estação de Biologia Marinha (EBM) of UFRRJ for the use of facilities. To Rafael B. de Moura for map drawing. This article is part of the D.Sc. thesis of the first author. Thanks are also to the Coordenação de Aperfeiçoamento Pessoal de Nível Superior (CAPES) for the D.Sc. fellowship to the first author. Shrimp samplings in Guanabara Bay and Sepetiba Bay were conducted under the authorization of Instituto Chico Mendes de Conservação da Biodiversidade (ICMBio), Brazilian Environmental Ministry (Licenses $n^{\circ}$ 27126-10 and $\mathrm{n}^{\circ}$ 27553-1).

\section{AUTHOR CONTRIBUTIONS}

Helena P. Lavrado and Karina A. Keunecke are responsible for the study conception and sampling design, supervision of the project and also contributed to the data analysis and to the writing of the manuscript. Cássia de Carvalho contributed to the study conception, carried out the field and labworks, performed data analysis and wrote the manuscript with input from the other authors.

\section{REFERENCES}

ALBERTONI EF, PALMA-SILVA C AND ESTEVES FA. 2003. Crescimento e fator de condição na fase juvenil de Farfantepenaeus brasiliensis (Latreille) e F paulensis (Pérez-Farfante) (Crustacea, Decapoda, Penaeidae) em uma lagoa costeira tropical do Rio de Janeiro, Brasil. Rev Bras Zool 20(3): 409-418.

ARAÚJO FG, GUIMARÃES FJ AND COSTA MR. 2006. Environmental influences on distribution of four Sciaenidae species (Actinopterygii, Perciformes) in a tropical bay at Southeastern Brazil. Rev Bras Biol 23(2): 497-508.

ARNOTT SA, NEIL DM AND ANSELL AD. 1998. Tailflip mechanism and size-dependent kinematics of escape swimming in the brown shrimp Crangon crangon. J Exp Biol 201: 1771-1784.

BALDRIDGE AK AND SMITH LD. 2008. Temperature constraints on phenotypic plasticity explain biogeographic patterns in predator trophic morphology. Mar Ecol Prog Ser 365: 25-34.
BALLESTER ELC, ABREU PC, CAVALLI RO, EMERENCIANO M, DE ABREU L AND WASIELESKY JR W. 2010. Effect of practical diets with different protein levels on the performance of Farfantepenaeus paulensis juveniles nursed in a zero exchange suspended microbial flocs intensive system. Aquac Nutr 16: 163-172.

BARCIA AR, LÓPEZ GE, HERNÁNDEZ D AND GARCÍAMACHADO E. 2005. Temporal variation of the population structure and genetic diversity of Farfantepenaeus notialis assessed by allozyme loci. Mol Ecol 14: 2933-2942.

BISSARO FG, GOMES-JR JL AND DI BENEDITTO AP. 2012. Morphometric variation in the shape of the cephalothorax of the shrimp Xiphopenaeus kroyeri on the east coast of Brazil. J Mar Biol Assoc UK 92(1): 1-9.

BRANCO JO AND VERANI JR. 1998a. Aspectos bioecológicos do camarão-rosa Penaeus brasiliensis Latreille (Natantia, Penaeidae) da Lagoa da Conceição, Santa Catarina, Brasil. Rev Bras Zool 15(2): 345-351.

BRANCO JO AND VERANI JR. 1998b. Estudo populacional do camarão-rosa Penaeus paulensis Pérez-Farfante (Natantia, Penaeidae) na Lagoa da Conceição, Santa Catarina, Brasil. Rev Bras Zool 15(2): 353-364.

BRIAN JV, FERNANDES T, LADLE RJ AND TODD PA. 2006. Patterns of morphological and genetic variability in UK populations of the shore crab, Carcinus maenas Linnaeus, 1758 (Crustacea: Decapoda: Brachyura). J Exp Mar Biol Ecol 329: 47-54.

BURKE JS, MONAGHAN JR JP AND YOKOYAMA S. 2000. Efforts to understand stock structure of summer flounder (Paralichthy sdentatus) in North Carolina, USA. J Sea Res 44: 111-122.

CADRIN SX. 2000. Advances in morphometric identification of fishery stocks. Rev Fish Biol Fish 10: 91-112.

CADRIN SX AND SILVA VM. 2005. Morphometric variation of yellowtail flounder. ICES J Mar Sci 62(4): 683-694.

CARVALHO-BATISTA A, NEGRI M, PILEGGI LG, CASTILHO AL, COSTA RC AND MANTELATTO FL. 2014. Inferring population connectivity across the range of distribution of the stiletto shrimp Artemesia longinaris Spence Bate, 1888 (Decapoda, Penaeidae) from DNA barcoding: implications for fishery management. ZooKeys 457: 271-288.

CASTILHO AL, GAVIO MA, COSTA RC, BOSCHI EE, BAUER RT AND FRANSOZO A. 2007. Latitudinal variation in population structure and reproductive pattern of the endemic South American shrimp Artemesia longinaris (Decapoda: Penaeoidea). J Crustac Biol 27: 548-552.

CASTILHO AL, PIE MR, FRANSOZO A, PINHEIRO AP AND COSTA RC. 2008. The relationship between environmental variation and species abundance in shrimp community (Crustacea: Decapoda: Penaeoidea) in southeastern Brazil. J Mar Biol Assoc UK 88(1): 119-123. 
CHOW S AND SANDIFER PA. 1991. Differences in growth, morphometrics traits, and male sexual maturity among Pacific white shrimp, Penaeus vannamei, from different commercial hatcheries. Aquaculture 92: 165-178.

CHU KH, CHEN QC, HUANG LM AND WONG CK. 1995. Morphometric analysis of commercially important penaeid shrimps from the Zhujiang estuary, China. Fish Res 23: 8393.

COHEN J. 1988. Statistical power analysis for the behavioral sciences, $2^{\text {nd }}$ ed., Hillsdale: Lawrence Erlbaum Associates, $567 \mathrm{p}$.

COSTA H. 1998. Uma avaliação da qualidade das águas costeiras do Estado do Rio de Janeiro. Rio de Janeiro: Fundação de Estudos do Mar - FEMAR, 261 p.

COSTA RC, FRANSOZO A, MELO GAS AND FREIRE FAM. 2003. Chave ilustrada para identificação dos camarões Dendrobranchiata do litoral norte do Estado de São Paulo, Brasil. Biota Neotrop 3(1): 1-12.

COSTA RC, LOPES M, CASTILHO AL, FRANSOZO A AND SIMÕES SM. 2008. Abundance and distribution of juvenile pink shrimps Farfantepenaeus spp. in a mangrove estuary and adjacent bay on the northern shore of São Paulo State, southeastern Brazil. Invertebr Repr Dev 52(12): 51-58.

DALL W, HILL BJ, ROTHLISBERG PC AND STAPLES DJ. 1990. The biology of the Penaeidae. Adv Mar Biol, n. 27. Academic Press, 487 p.

DA SILVA JR DR, PARANHOS R AND VIANNA M. 2016. Spatial patterns of distribution and the influence of seasonal and abiotic factors on demersal ichthyofaunal in an estuarine tropical bay. J Fish Biol 89: 821-846.

DIAS NETO J. 2011. Proposta de Plano Nacional de Gestão para o uso sustentável de Camarões marinhos do Brasil / José Dias Neto, Organizador. - Brasília: Ibama, 242 p.

D’INCAO F. 1991. Pesca e biologia da Penaeus paulensis na Lagoa dos Patos, RS. Atlântica 13(1): 159-169.

D'INCAO F, VALENTINI H AND RODRIGUES LF. 2002. Avaliação da pesca de camarões nas regiões sudeste e sul do Brasil: 1965-1999. Atlântica 24: 103-116.

DUMONT LFC AND D'INCAO F. 2010. Biometric relationships of the Argentinean prawn Artemesia longinaris (Decapoda: Penaeidae) in the south-western Atlantic. J Mar Biol Assoc UK 90(7): 1385-1393.

FERREIRA NC AND FREIRE AS. 2009. Spatio-temporal variation of the pink shrimp Farfantepenaeus paulensis (Crustacea, Decapoda, Penaeidae) associated to the seasonal overture of the sandbar in a subtropical lagoon. Iheringia, Ser Zool 99(4): 390-396.

FIORI CS, RODRIGUES APC, SANTELLI RE, CORDEIRO RC, CARVALHEIRA RG, ARAÚJO PC, CASTILHOS ZC AND BIDONI ED. 2013. Ecological risk index for aquatic pollution control: a case study of coastal water bodies from the Rio de Janeiro State, southeastern Brazil. Geoch Bras 27(1): 24-36.

FISHER RA. 1930. The Genetical Theory of Natural Selection. Oxford: Oxford University Press, 308 p.

FREITAS JR F, FRACASSO HAA, BRANCO JO AND CHRISTOFFERSEN ML. 2011. Ten-year variations in population structure of pink-shrimp in a Southwestern Atlantic Bay affected by highway construction. Braz J Ocean 59(4): 377-390.

GARCIA S AND LE RESTE L. 1981. Life cycles, dynamics, exploitation and management of coastal penaeid shrimp stocks. FAO Fish Tech Pap 203: 1-215.

GEISEL JT. 1972. Sex ratio, rate of evolution, and environmental heterogeneity. Am Nat 106: 380-387.

GEO-RIO - FUNDAÇÃO INSTITUTO DE GEOTÉCNICA. 2013. Relatório anual de chuva para a cidade do Rio de Janeiro. Relatório GEO-RIO/DEP/GPE - 06/2013, 153 p.

GOMES APP, KEUNECKE KA, SILVA JR DR AND VIANNA M. 2013. Modulating reproduction of Penaeidae shrimps: ecological responses of two sympatric species (Decapoda: Dendrobranchiata) on south-eastern Brazilian coast. J Mar Biol Assoc UK 93(3): 733-740.

GUSMÃO J, LAZOSKI C AND SOLÉ-CAVA AM. 2005. Population genetic structure of Brazilian shrimp species (Farfantepenaeus sp., F. brasiliensis, F. paulensis and Litopenaeus schmitti: Decapoda: Penaeidae). Genet Mol Biol 28(1): 165-171.

KEVREKIDIS K AND THESSALOU-LEGAKI M. 2006. Catch rates, size structure and sex ratio of Melicertus kerathurus (Decapoda: Penaeidae) from an Aegean Sea trawl fishery. Fish Res 80: 270-279.

KJERFVE B, RIBEIRO CHA, DIAS GTM, FILIPPO AMAND QUARESMA VDS. 1997. Oceanographic characteristics of na impacted coastal bay: Baía de Guanabara, Rio de Janeiro, Brazil. Cont Shelf Res 17: 1609-1643.

LAVRADO HP, FALCÃO APC, CARVALHO-CUNHA P AND SILVA SHG. 2000. Composition and distribution of Decapoda from Guanabara Bay, RJ. Nauplius 8(1): 15-23.

LEITE JR NO AND PETRERE JR M. 2006. Growth and mortalities of the pink-shrimp Farfantepenaeus brasiliensis Latreille, 1970 and F. paulensis Pérez-Farfante 1967 in Southeast Brazil. Braz J Biol 66(2A): 523-536.

LÜCHMANN KH, FREIRE A, FERREIRA NC, DAURAJORGE FG AND MARQUES MRF. 2008. Spatial and temporal variations in abundance and biomass of penaeid shrimps in the subtropical Conceição Lagoon, southern Brazil. J Mar Biol Assoc UK 88(2): 293-299.

MORAES MCM AND LAVRADO HP. 2017. Distribution of loliginid squids in a eutrophicated tropical coastal bay. Mar Biol Res 13(3): 330-341.

NETO JER. 1985. Relações biométricas para camarão-rosa (Penaeus brasiliensis e Penaeus paulensis) na região Sul do Brasil. Superintendência do Desenvolvimento da Pesca 
- SUDEPE. Instituto de Pesquisa e Desenvolvimento Pesqueiro - PDP. Centro de Pesquisa e Extensão Pesqueira da Região Sudeste/Sul - CEPSUL. Itajaí, SC. Sér Doc Téc 2, $34 \mathrm{p}$.

O'NEILL B, KEIRSE G, McGRATH DE AND BROPHY D. 2012. Scales of variability in fin ray counts of flounder Platichthys flesus L. on Irish and Welsh Coasts. Biol Environ Proc R Ir Acad 112B: 185-191.

OSHIRO LMY AND ARAÚJO FG. 1987. Estudo preliminar de peixes jovens e crustáceos decápodos da Baía de Sepetiba, RJ. ACIESP 3(54): 283-297.

PAIVA MP AND FONTELES-FILHO AA. 2004. Espécies, sexos e tamanhos do camarão-rosa, Farfantepenaeus spp., no estado do Rio de Janeiro (Brasil). Arq Ciên Mar 37: 139-143.

PARAMO J AND SAINT-PAUL U. 2010. Morphological differention of souther pink shrimp Farfantepenaeus notialis in Colombian Caribbean Sea. Aquat Living Resour 2: 95-101.

PÉREZ-FARFANTE I. 1967. A new species and two new subspecies of shrimp of the genus Penaeus from the Western Atlantic. Proc Biol Soc Wash 80: 83-99.

PURUSHOTHAMAN P, CHAKRABORTY RD, KUBERAN G, MAHESWARUDU G, BABY PK, SREESANTH L, RAGESH N AND PAZHAYAMADOM DG. 2017. Stock structure analysis of 'Aristeus alcocki Ramadan, 1938 (Decapoda: Aristeidae)' in the Indian coast with truss network morphometrics. Can J Zool 96(5): 411-424.

RIBEIRO CHA AND KJERFVE B. 2002. Anthropogenic influence on the water quality in Guanabara Bay, Rio de Janeiro, Brazil. Reg Environ Change 3: 13-19.

SANTI T AND TAVARES M. 2009. Polychaete assemblage of an impacted estuary, Guanabara Bay, Rio de Janeiro, Brazil. Braz J Ocean 57(4): 287-303.

SEMADS - SECRETARIA DE ESTADO DE MEIO AMBIENTE E DESENVOLVIMENTO SUSTENTÁVEL. 2001. Bacias Hidrográficas e Recursos Hídricos da Macrorregião Ambiental 2 - Bacia da Baía de Sepetiba Rio de Janeiro, 80 p.

SILVA IC, HAWKINS SJ AND PAULA J. 2009. A comparison of population differentiation in two shore crab species with contrasting distribution along the Portuguese coast, using two morphological methodologies. Mar Freshwater 60: 833-844.

SMITH LD. 2004. Biogeographic differences in claw size and performance in an introduced crab predator Carcinus maenas. Mar Ecol Prog Ser 276: 209-222.

SOARES-GOMES A, DA GAMA BAP, BAPTISTA NETO JA, FREIRE DG, CORDEIRO RC, MACHADO W, BERNARDES MC, COUTINHO R, THOMPSON FL AND PEREIRA RC. 2016. An environmental overview of Guanabara Bay, Rio de Janeiro. Reg Mar Sci 8: 319-330.

SUN MM, HUANG JH, JIANG SG, YANG QB, ZHOU FL, ZHU CY, YANG LS AND SU TF. 2014. Morphometric analysis of four different populations of Penaeus monodon (Crustacea, Decapoda, Penaeidae). Aquacult Res 45: 113123.

TEODORO SSA, TEROSSI M, COSTA RC AND MANTELATTO FL. 2015. Genetic homogeneity in the commercial pink shrimp Farfantepenaeus paulensis revealed by COI barcoding gene. Estuar Coast Shelf Sci 166: 124-130.

TEODORO SSA, TEROSSI M, MANTELATTO FL AND COSTA RC. 2016. Discordance in the identification of juvenile pink shrimp (Farfantepenaeus brasiliensis and F. paulensis: Family Penaeidae): An integrative approach using morphology, morphometry and barcoding. Fish Res 183: 244-253.

VALENTINI H, D'INCAO F, RODRIGUES LF AND DUMONT LF. 2012. Evolução da pescaria industrial de camarão-rosa (Farfantepenaeus brasiliensis e F. paulensis) na costa Sudeste e Sul do Brasil - 1968-1989. Atlântica 34(2): 157-171.

VIANNA M. 2009. A Produção Pesqueira do Estado do Rio de Janeiro. In: Vianna M, Diagnóstico da cadeia produtiva da pesca marítima no Estado do Rio de Janeiro: relatório de pesquisa. Rio de Janeiro: FAERJ, SEBRAE-RJ, 200 p.

ZAR JH. 1999. Biostatistical Analysis. Fourth edition, Prentice-Hall, Englewood Cliffs, New Jersey, 662 p. 